\title{
India's Renaissance: Leadership in Every Sphere on the International Stage
}

\author{
Jatavath Hanumu \\ MA Political Science, (UGC - NET Qualified), Osmania University, Hyderabad, India
}

\begin{abstract}
In the human history man was gregarious. So the groups of people fought each other for control over the lands and nature. So when the centuries passed kingdoms tried to control there never kingdoms and succeed in some extent. On this account empire obtained taxes from princely states. In this regard Greeks tried to expert their kingdom till the ends of the world. On this account the Greek warrior son of the Philip of Macedonia Alexander The Great conquered the entire world and controlled politically with his leadership. Later on Romans extended their kingdom and ruled for some centuries under the leadership of Antonio and Julius Ceasor. In the course of time European navigators discovered the new lands of the entire world. So Dutch people, French people, Porchuguice people and English people competed with one another to control over the geographical territories and natural recourses. They also asserted their power over the lands. At last queen's English army could have control over many colonies in the world. So many centuries they ruled and drove the wealth of the nations to England in the name of the trade and "civilizing the uncivilized eastern lands". In the post independent era India is considered as the developing nation in the world and in the post modern era India leads the world in field and became a leader to the world. So the preset investigation is on India's leadership in the world and its achievements. The major focus is on the political leadership of India in the world.
\end{abstract}

Keywords: leadership, India, Greek warrior, English, world, Development

\section{Introduction}

In the human history man was gregarious. So the groups of people fought each other for control over the lands and nature. So when the centuries passed kingdoms tried to control there never kingdoms and succeed in some extent. On this account empire obtained taxes from princely states. In this regard Greeks tried to expert their kingdom till the ends of the world. On this account the Greek warrior son of the Philip of Macedonia Alexander the Great conquered the entire world and controlled politically with his leadership. Later on Romans extended their kingdom and ruled for some centuries under the leadership of Antonio and Julius Ceasor. In the course of time European navigators discovered the new lands of the entire world. So Dutch people, French people, Porchuguice people and English people competed with one another to control over the geographical territories and natural recourses. They also asserted their power over the lands.

At last queen's English army could have control over many colonies in the world. So many centuries they ruled and drove the wealth of the nations to England in the name of the trade and "civilizing the uncivilized eastern lands". In the post independent era India is considered as the developing nation in the world and in the post modern era India leads the world in field and became a leader to the world. So the preset investigation is on India's leadership in the world and its achievements. The major focus is on the political leadership of India in the world.

After decolonization, third world countries made more efforts to rebuild their economies. These commonwealth countries reunited with the European and Western countries to develop trade and exchange of research and science and technology. So for the international cooperation and justice a new organization was established known as "United Nations Organization" (UNO) eastern and western countries are members of this organization there are permanent members with "Veto Power" there are also some members without Veto Power. On this account countries also numbers of the "United Nations Organization" (UNO); some super power nations are controlling the developing and under the developed nations to posses there natural resources just as America controlling over Arabian countries so they killed Saddam Husseian and Gadaafi for raising against the will of USA government. Further this hegemony is in continuation since many decades as a result of it there is outbreak of terrorism by Muslim fundamentalists and some of the organizations.

Because of this international phenomena India is also victim of terrorism. Indeed there are many reasons behind this spread of terrorism in India such as the problem of Kashmir to integrate as the part of Pakistan and advocating and taking part in the international affairs and communal rights between Hindu and Muslim fundamentalists. In this regard it is noteworthy to recall the tragedies of attack on parliament, attack on Taj Deccan Hotel in Mumbai and Gokul Chat in Hyderabad. India plays key role in world leadership by launching the satilite vacates for chief rates such as 104 satellites by a single rocket.

In this regard the super power nation United States of America (USA) depends on Indian aeronautical institutions such as ISRO and DRDO. India surpassed its height in passing the nuclear power by conducting nuclear tests many times. Further India attends for conferences of the world on environmental safely. In the recent years India also collaborates with the world by the program of world intellectual forum NITIAYOG under the leadership of Primeminister, Mr. Narendra Modi. In addition to this India represents in games and sports. Besides these aspects India also stood first in sending astronaut Rakesh Sharma from Hyderabad into space. On account this India excelled in launching satellite to the Mars and became successful in a few successful countries. Further India also has other 
objectives such as journey to Moon by the by rocket with man. Besides these aspects India enlarges its scope in foreign relations with the entire world wherever there is possibility to trade and exchange of culture.

In conclusion the prominent aspects of the discourse are "the significance of Indian sub continent relation" since the history of the civilizations in the fields of socio, economic, political religious, cultural, traditional, educational and scientific aspects. Further the present research analyzed the merits of Indian sub continent and its advances in various fields particularly in the area of science and technology and economy. Further the noticed aspects are the significance of Indian economy in transition towards the progress in the age of Liberalization, Privatization and Globalization. India stands first place in the world "as a leader" to lead the entire world community and for all the countries.

\section{References}

[1] Agrahari Ravi P., Science And Technology, Mcgrawhill Education, Hyderabad: 2018.

[2] Khanna V. N. Leslie Kumar, Foreign Policy of India, Vikas Publishing House, New Delhi: 2018.

[3] Kahlmeyer Andre, Sayyid Qutb - An Islamic Fundamentalist, Grin Verlag, Munich: 2003.

[4] Reddy Krishna, World History, Mcgrawhill Education, Hyderabad: 2017.

[5] Reddy Krishna, Indian History, Mcgrawhill Education, Hyderabad: 2017.

[6] Ratnaparkhi M. S, Kashmir Problem And Its Solutions, Atlantic Publishers and Distributers Pvt ltd, New Delhi: 2017.

[7] Riggs Robert Plano Jackc. Ziring Lawrence, The United Nations: International Organizations And World Politics, Wards Worth Publishing Coinc, Belmont: 2004.

[8] Raychaudhuri Ajitava De Prabir, International Trade in Services In India, Oxford University Press, London: 2012.

[9] Sonvane Smitha S., Terrorism in India And Abrod, Kalpaj Publications, New Delhi: 2011.

[10] Spectrum Book of Editorial Team, International Organizations, Conferences And Treaties, Spectrum Book Pvt Ltd, Delhi: 2018.

\section{Webliography}

[11] https: //en. wikipedia. org/wiki/World_history

[12] https: //en. wikipedia. org/wiki/History_of_India

[13] https: //www.quora. com/What - is - the - problem - in - Kashmir

[14] https: //www.dailypioneer. com/2018/india abroad/india - - south - korea - decide - to - ramp - up anti - terror - cooperation. html

[15] https: //en. wikipedia. org/wiki/Science_and_technology_in_India

[16] https: //en. wikipedia. org/wiki/United_Nations

[17] https: //en. wikipedia. org/wiki/Foreign_relations_of_India

[18] https: //en. wikipedia. org/wiki/Islamic_fundamentalism

[19] https: //www.allconferencealerts. com/?gclid=CjwKCAiA1ZDiBRAXEiwAIWyNC_O9
f4o0upsbT67FZr4EpsOblrN3TcE8OiDLkQuBBUOTF c - itV1arBoCENAQAvD_BwE

[20] https: //en. wikipedia. org/wiki/Foreign_trade_of_India 